\title{
Mitigation of Particulate Matter and Airborne Pathogens in Swine Barn Emissions with Filtration and UV-A Photocatalysis
}

\author{
Myeongseong Lee ${ }^{1}{ }^{\oplus}$, Jacek A. Koziel ${ }^{1, *}{ }^{\oplus}$, Nubia R. Macedo ${ }^{2}$, Peiyang Li $^{1}{ }^{1}$, Baitong Chen ${ }^{1} \oplus$, \\ William S. Jenks ${ }^{3}$, Jeffrey Zimmerman ${ }^{2}$ and R. Vincent Paris 4 \\ 1 Department of Agricultural and Biosystems Engineering, Iowa State University, Ames, IA 50011, USA; \\ leefame@iastate.edu (M.L.); peiyangl@iastate.edu (P.L.); baitongc@iastate.edu (B.C.) \\ 2 Department of Veterinary Diagnostic and Production Animal Medicine, Iowa State University, \\ Ames, IA 50011, USA; nubia@iastate.edu (N.R.M.); jjzimm@iastate.edu (J.Z.) \\ 3 Department of Chemistry, Iowa State University, Ames, IA 50011, USA; wsjenks@iastate.edu \\ 4 Department of Statistics, Iowa State University, Ames, IA 50011, USA; vinny@iastate.edu \\ * Correspondence: koziel@iastate.edu; Tel.: +1-515-294-4206
}

Citation: Lee, M.; Koziel, J.A.; Macedo, N.R.; Li, P.; Chen, B.; Jenks, W.S.; Zimmerman, J.; Paris, R.V. Mitigation of Particulate Matter and Airborne Pathogens in Swine Barn Emissions with Filtration and UV-A Photocatalysis. Catalysts 2021, 11, 1302. https://doi.org/10.3390/ catal11111302

Academic Editors: Wonyong Choi, Detlef W. Bahnemann,

Ioannis Konstantinou, Ewa Kowalska, Magdalena Janus, Vincenzo Vaiano and Zhi Jiang

Received: 8 October 2021

Accepted: 26 October 2021

Published: 28 October 2021

Publisher's Note: MDPI stays neutral with regard to jurisdictional claims in published maps and institutional affiliations.

Copyright: (c) 2021 by the authors. Licensee MDPI, Basel, Switzerland. This article is an open access article distributed under the terms and conditions of the Creative Commons Attribution (CC BY) license (https:/ / creativecommons.org/licenses/by/ $4.0 /)$.

\begin{abstract}
This study evaluated the use of filtration and UV-A photocatalysis for the reduction of particulate matter (PM) and airborne bacterial pathogens in swine barns. Two MERV filters (8 and 15) were used to mitigate PM concentrations measured at the PM 1, PM 2.5, respirable PM, and PM 10 ranges. Filtration was also used to generate different levels of airborne pathogens to be treated by UV-A. Results show that MERV 8 and 15 filters effectively reduced PM concentrations (96-98\%) in air exhausted from a swine barn ( $p$ ranged from $<0.01$ to 0.04 ). UV-A photocatalysis did not mitigate PM concentrations. UV-A photocatalysis treatment reduced measured colony-forming units (CFUs) by 15-95\%. The CFU percent reduction was higher when airborne PM concentration was low. The numeric results suggested a real mitigation effect despite $p$-values that did not meet the usual statistical cut-off of $<0.05$ for significance due to the large variability of the CFU control samples. Normalization of measured airborne pathogen concentrations by smaller PM size range concentrations led to emerging significant treatment differences for CFUs. A significant decrease $(\sim 51 \%$ reduction; $p<0.02)$ in the concentration of viable airborne bacteria was shown for all PM below the 10 micron range.
\end{abstract}

Keywords: air pollution control; biosecurity; animal diseases; ultraviolet light; advanced oxidation; filtration; environmental technology

\section{Introduction}

Bioaerosols composed of organic dust (proteins, complex carbohydrates), microorganisms (viruses, bacteria, and fungi), and endotoxins are believed to contribute to respiratory infections in workers and livestock [1-3]. Thus, human and animal health could benefit from improved air quality and reduced exposure to airborne pathogens inside barns. Air filtration can mitigate particulate matter (PM) and reduce airborne infectious pathogens, and some swine operations use high-efficiency particulate air (HEPA) filters to remove dust and infectious airborne from incoming ventilation air [4]. While inlet air filtration can reduce exposure to airborne pathogens and PM [5,6], it is expensive to install and maintain (e.g., the estimated maintenance cost for inlet air HEPA filters for a typical swine barn is $>\$ 80,000$ per year [4]).

Ultraviolet (UV) light can mitigate pathogens and gases, but the bactericidal effects depend on the wavelength, dose, and other factors that challenge the techno-economic considerations for farm-scale adoption [7]. The light within the UV portion of the spectrum (wavelengths 100-400 nm) exhibits widely different effects, not only because of the fourfold range of energy per photon but because of absorption probabilities that vary by orders of magnitude for different materials and wavelengths. 
The 100-290 nm range (commonly referred to as "UV-C") is the most energetic and most universally absorbed, although even within that range, enormous differences in effect among wavelengths are observed because of variation in absorption. In fact, the range of 100-200 nm is often referred to as the Vacuum UV because these wavelengths are strongly absorbed by the ordinary components of air (and thus can only be transmitted in a vacuum), which means that for many applications, the practical UV-C range is roughly 200-290 nm. Nonetheless, even this range is considered bactericidal and most "bactericidal lights" are usually $254 \mathrm{~nm}$ lamps. Unfortunately, even the more practical 200-290 nm range sources (including the common $254 \mathrm{~nm}$ lamps) are more dangerous and toxic to humans and animals than longer wavelengths.

Alternatively, UV-A (320-400 nm) has the longest wavelength in the UV spectrum and is the least toxic. In broad terms, this is because it is absorbed by the fewest materials. However, that selectivity can be used to advantage in some cases because only certain things are affected. The $254 \mathrm{~nm}$ lamps are much more effective for use in cases where direct irradiation is desired and human or animal exposure can be avoided. However, coupling UV-A irradiation with a semiconductor photocatalyst that absorbs these wavelengths and produces surface-bound oxidative intermediates has been proven effective in mitigating air pollutants in animal agriculture. Costa et al. [8] and Guarino et al. [9] reported that

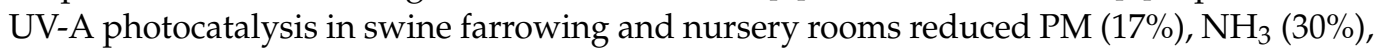
and selected greenhouse gases (GHGs) $\left(\mathrm{CH}_{4}: \sim 27 \%, \mathrm{CO}_{2}: \sim 15 \%\right)$, while improving feed conversion efficiency (12\%). Follow-up research consistently reported the benefits of UV-A photocatalysis to mitigate livestock odor and gaseous emissions [10-20].

To date, there are no farm-scale data on the performance of UV-A photocatalysis in mitigating airborne pathogens in U.S.-based swine production facilities. Therefore, we conducted an on-farm study on mitigating airborne bacterial pathogens emitted from swine barn using PM filtration and UV-A photocatalysis. Two HEPA (high-efficiency particulate air) filters (MERV 8 and MERV 15 efficiency) were used to mitigate PM concentrations measured at the PM 1, PM 2.5, respirable PM, PM10, and total PM size ranges. To be clear, there was no expectation for photocatalysis or direct irradiation to directly affect the nonviable fraction of PM. The effect of UV-A photocatalysis on bacteria (sometimes referred to as 'viable $\mathrm{PM}^{\prime}$ ') was measured using filtration to control PM concentration and generate specific concentrations of airborne bacterial pathogens, as measured in colony-forming units (CFU). The concept of the experimental design is shown in Figure 1.

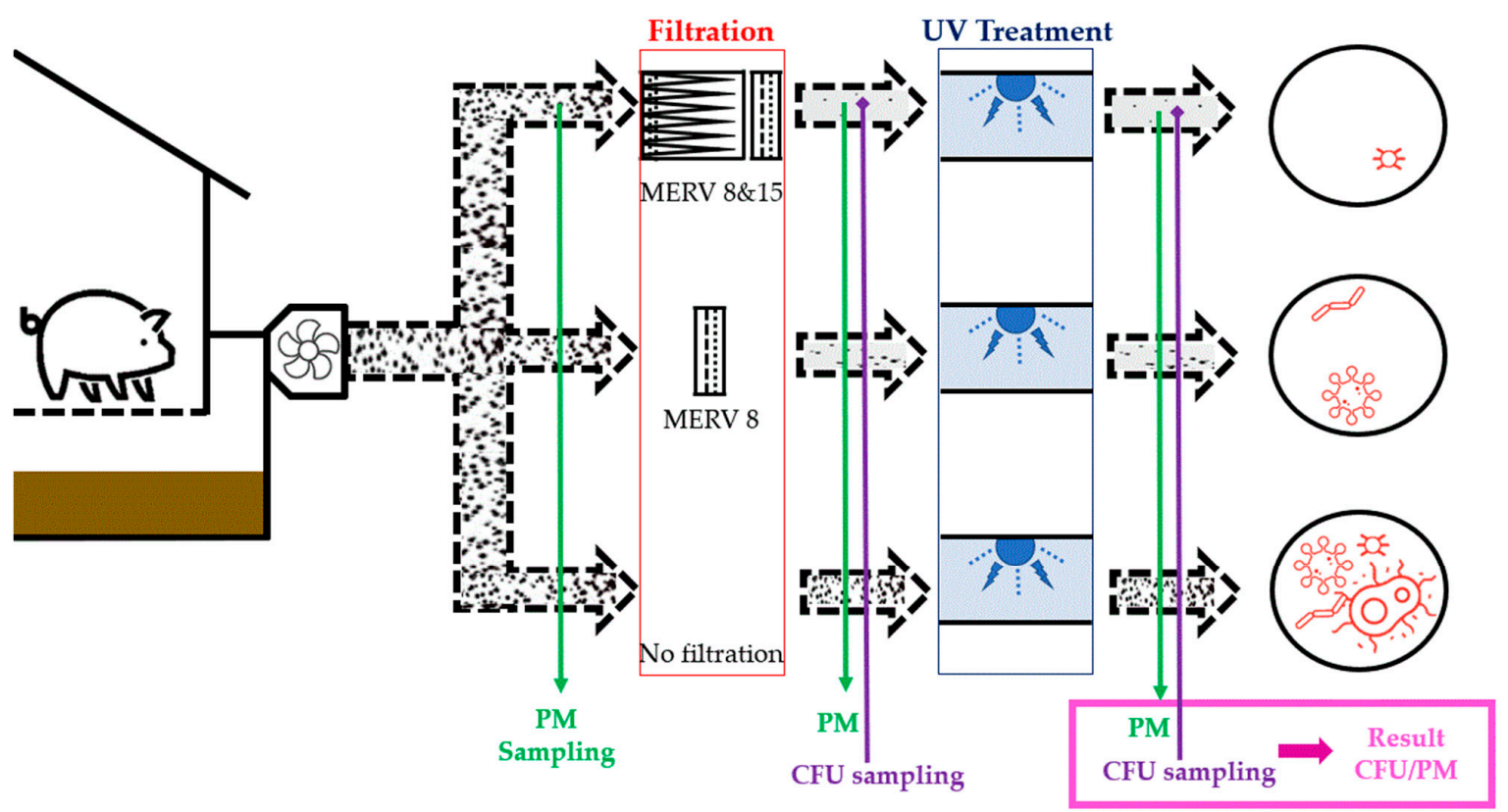

Figure 1. Mitigation of particulate matter (PM) and airborne pathogens in swine barn emissions with filtration and UV-A photocatalysis. Overview of experimental design and reporting of the mitigation effect. The UV-A treatment was performed under three PM loads: the 'best-case' (MERV 8 and 15), 'midpoint' (MERV 8), and 'worst-case' (no filtration). 


\section{Results and Discussion}

\subsection{Treatment of PM by HEPA Filtration and UV-A Photocatalysis}

The effect of HEPA filtration and UV-A photocatalysis on PM was investigated under three conditions with increasingly higher PM concentrations. The 'best-case', 'midpoint', and 'worst-case' scenarios (Figure 1) were achieved by air filtration before the UV treatment (Tables 1-3). Table 1 reports the results when MERV 8 and 15 filters removed 96-98\% of incoming PM, and the treatment conditions reflect the low dust concentration, (i.e., the 'best-case' scenario). Table 2 reports the results when the MERV 8 was used to remove $77-86 \%$ of incoming PM (i.e., the 'midpoint' scenario). Finally, Table 3 reports the results for unfiltered exhaust from the manure pit fan (i.e., the 'worst-case' scenario). Notably, UV-A photocatalysis did not affect the PM concentration under any of the three scenarios.

Table 1. Particulate matter removal performance of the MERV 8 and 15 (Treatment I) and UV-A photocatalysis (Treatment

II) in mitigating PM (the 'best-case' scenario). Bold signifies statistical significance.

\begin{tabular}{|c|c|c|c|c|c|c|c|c|c|c|}
\hline & \multicolumn{2}{|c|}{ Total PM } & \multicolumn{2}{|c|}{ PM 10} & \multicolumn{2}{|c|}{ Respirable PM } & \multicolumn{2}{|c|}{ PM 2.5} & \multicolumn{2}{|c|}{ PM 1} \\
\hline & $\underset{\left(\mathrm{mg} \cdot \mathrm{m}^{-3}\right)}{\text { Conc }}$ & $\begin{array}{c}\% \mathbf{R} \\
\text { (p-Value) }\end{array}$ & $\begin{array}{c}\text { Conc } \\
\left(\mathrm{mg} \cdot \mathrm{m}^{-3}\right)\end{array}$ & $\begin{array}{c}\% \mathbf{R} \\
(p \text {-Value) }\end{array}$ & $\begin{array}{c}\text { Conc } \\
\left(\mathrm{mg} \cdot \mathrm{m}^{-3}\right)\end{array}$ & $\begin{array}{c}\% \mathbf{R} \\
\text { (p-Value) }\end{array}$ & $\begin{array}{c}\text { Conc } \\
\left(\mathrm{mg} \cdot \mathrm{m}^{-3}\right)\end{array}$ & $\begin{array}{c}\% \mathbf{R} \\
\text { ( } p \text {-Value) }\end{array}$ & $\begin{array}{c}\text { Conc } \\
\left(\mathrm{mg} \cdot \mathrm{m}^{-3}\right)\end{array}$ & $\begin{array}{c}\% \mathbf{R} \\
(p \text {-Value })\end{array}$ \\
\hline $\begin{array}{l}\text { Control } \\
\text { (before filtration, } \\
\text { sampling port 1) }\end{array}$ & $\begin{array}{c}0.224 \\
\pm 0.161\end{array}$ & - & $\begin{array}{c}0.104 \\
\pm 0.128\end{array}$ & - & $\begin{array}{c}0.094 \\
\pm 0.108\end{array}$ & - & $\begin{array}{c}0.084 \\
\pm 0.084\end{array}$ & - & $\begin{array}{c}0.105 \\
\pm 0.067\end{array}$ & - \\
\hline $\begin{array}{c}\text { Treatment I } \\
\text { (after MERV } 8 \text { and } \\
15 \text { filtration, } \\
\text { sampling port 2) }\end{array}$ & $\begin{array}{c}0.0037 \\
\pm 0.0008\end{array}$ & $\begin{array}{c}98.3 \\
(0.01)\end{array}$ & $\begin{array}{c}0.0033 \\
\pm 0.0005\end{array}$ & $\begin{array}{c}96.8 \\
(0.01)\end{array}$ & $\begin{array}{c}0.0031 \\
\pm 0.0004\end{array}$ & $\begin{array}{c}96.7 \\
(0.03)\end{array}$ & $\begin{array}{c}0.0031 \\
\pm 0.0004\end{array}$ & $\begin{array}{c}96.3 \\
(0.04)\end{array}$ & $\begin{array}{c}0.0031 \\
\pm 0.0004\end{array}$ & $\begin{array}{c}97.0 \\
(<0.01)\end{array}$ \\
\hline $\begin{array}{c}\text { Treatment II } \\
\text { (after UV-A, } \\
\text { sampling port 3) }\end{array}$ & $\begin{array}{c}0.0037 \\
\pm 0.0008\end{array}$ & $\begin{array}{c}0 \\
(1.00)\end{array}$ & $\begin{array}{c}0.0031 \\
\pm 0.0004\end{array}$ & $\begin{array}{c}4.5 \\
(0.35)\end{array}$ & $\begin{array}{c}0.003 \\
\pm 0.0004\end{array}$ & $\begin{array}{c}0 \\
(1.00)\end{array}$ & $\begin{array}{c}0.0030 \\
\pm 0.0000\end{array}$ & $\begin{array}{c}4.8 \\
(0.35)\end{array}$ & $\begin{array}{c}0.0030 \\
\pm 0.0000\end{array}$ & $\begin{array}{c}4.8 \\
(0.35)\end{array}$ \\
\hline
\end{tabular}

Note: Conc $=$ concentration, $\% \mathrm{R}=$ percent reduction, UV-A dose $=5.3 \mathrm{~mJ} \cdot \mathrm{cm}^{-2}$; sampling port numbers and locations are illustrated in Methods.

Table 2. Particulate matter removal performance of the MERV 8 (Treatment I) and UV-A photocatalysis (Treatment II) in mitigating PM (the 'midpoint' scenario).

\begin{tabular}{|c|c|c|c|c|c|c|c|c|c|c|}
\hline & \multicolumn{2}{|c|}{ Total PM } & \multicolumn{2}{|c|}{ PM 10} & \multicolumn{2}{|c|}{ Respirable PM } & \multicolumn{2}{|c|}{ PM 2.5} & \multicolumn{2}{|c|}{ PM 1} \\
\hline & $\begin{array}{c}\text { Conc } \\
\left(\mathrm{mg} \cdot \mathrm{m}^{-3}\right)\end{array}$ & $\begin{array}{c}\% \mathbf{R} \\
(p \text {-Value) }\end{array}$ & $\underset{\left(\mathrm{mg} \cdot \mathrm{m}^{-3}\right)}{\text { Conc }}$ & $\begin{array}{c}\% \mathbf{R} \\
(p \text {-Value) }\end{array}$ & $\begin{array}{c}\text { Conc } \\
\left(\mathrm{mg} \cdot \mathrm{m}^{-3}\right)\end{array}$ & $\begin{array}{c}\% \mathbf{R} \\
(p \text {-Value) }\end{array}$ & $\begin{array}{c}\text { Conc } \\
\left(\mathrm{mg} \cdot \mathrm{m}^{-3}\right)\end{array}$ & $\begin{array}{c}\% \mathbf{R} \\
(p \text {-Value) }\end{array}$ & $\begin{array}{c}\text { Conc } \\
\left(\mathrm{mg} \cdot \mathrm{m}^{-3}\right)\end{array}$ & $\begin{array}{c}\% \mathbf{R} \\
(p \text {-Value) }\end{array}$ \\
\hline $\begin{array}{l}\text { Control } \\
\text { (before filtration, } \\
\text { sampling port 1) }\end{array}$ & $\begin{array}{c}0.267 \\
\pm 0.241\end{array}$ & - & $\begin{array}{c}0.205 \\
\pm 0.185\end{array}$ & - & $\begin{array}{c}0.153 \\
\pm 0.175\end{array}$ & - & $\begin{array}{c}0.146 \\
\pm 0.174\end{array}$ & - & $\begin{array}{c}0.143 \\
\pm 0.174\end{array}$ & - \\
\hline $\begin{array}{c}\text { Treatment I } \\
\text { (after MERV 8, } \\
\text { sampling port 2) }\end{array}$ & $\begin{array}{c}0.061 \\
\pm 0.028\end{array}$ & $\begin{array}{c}77.1 \\
(0.055)\end{array}$ & $\begin{array}{c}0.048 \\
\pm 0.018\end{array}$ & $\begin{array}{c}76.6 \\
(0.056)\end{array}$ & $\begin{array}{c}0.027 \\
\pm 0.009\end{array}$ & $\begin{array}{c}82.6 \\
(0.09)\end{array}$ & $\begin{array}{c}0.022 \\
\pm 0.007\end{array}$ & $\begin{array}{c}84.7 \\
(0.10)\end{array}$ & $\begin{array}{c}0.020 \\
\pm 0.006\end{array}$ & $\begin{array}{c}86.3 \\
(0.10)\end{array}$ \\
\hline $\begin{array}{c}\text { Treatment II } \\
\text { (after UV-A, } \\
\text { sampling port 3) }\end{array}$ & $\begin{array}{c}0.061 \\
\pm 0.016\end{array}$ & $\begin{array}{c}0.7 \\
(0.96)\end{array}$ & $\begin{array}{c}0.050 \\
\pm 0.011\end{array}$ & $\begin{array}{l}-3.2 \\
(0.84)\end{array}$ & $\begin{array}{c}0.029 \\
\pm 0.005\end{array}$ & $\begin{array}{l}-7.0 \\
(0.61)\end{array}$ & $\begin{array}{c}0.024 \\
\pm 0.005\end{array}$ & $\begin{array}{l}-7.1 \\
(0.62)\end{array}$ & $\begin{array}{c}0.023 \\
\pm 0.005\end{array}$ & $\begin{array}{l}-14.9 \\
(0.24)\end{array}$ \\
\hline
\end{tabular}

Note: Conc $=$ concentration, $\% \mathrm{R}=$ percent reduction, $\mathrm{UV}-\mathrm{A}$ dose $=5.3 \mathrm{~mJ} \cdot \mathrm{cm}^{-2}$; sampling port numbers and locations are illustrated in Methods.

Table 3. Particulate matter removal performance of UV-A photocatalysis (Treatment II) in mitigating PM under no filtration condition (the 'worst-case' scenario).

\begin{tabular}{|c|c|c|c|c|c|c|c|c|c|c|}
\hline & \multicolumn{2}{|c|}{ Total PM } & \multicolumn{2}{|c|}{ PM 10} & \multicolumn{2}{|c|}{ Respirable PM } & \multicolumn{2}{|c|}{ PM 2.5} & \multicolumn{2}{|c|}{ PM 1} \\
\hline & $\begin{array}{c}\text { Conc } \\
\left(\mathrm{mg} \cdot \mathrm{m}^{-3}\right)\end{array}$ & $\begin{array}{c}\% \mathbf{R} \\
(p \text {-Value })\end{array}$ & $\begin{array}{c}\text { Conc } \\
\left(\mathrm{mg} \cdot \mathrm{m}^{-3}\right)\end{array}$ & $\begin{array}{c}\% \mathbf{R} \\
(p \text {-Value) }\end{array}$ & $\begin{array}{c}\text { Conc } \\
\left(\mathrm{mg} \cdot \mathrm{m}^{-3}\right)\end{array}$ & $\begin{array}{c}\% \mathbf{R} \\
(p \text {-Value })\end{array}$ & $\begin{array}{c}\text { Conc } \\
\left(\mathrm{mg} \cdot \mathrm{m}^{-3}\right)\end{array}$ & $\begin{array}{c}\% \text { R } \\
(p \text {-Value) }\end{array}$ & $\begin{array}{c}\text { Conc } \\
\left(\mathrm{mg} \cdot \mathrm{m}^{-3}\right)\end{array}$ & $\begin{array}{c}\% \mathbf{R} \\
(p \text {-Value })\end{array}$ \\
\hline $\begin{array}{c}\text { Control } \\
\text { (Sampling port 1) }\end{array}$ & $\begin{array}{c}0.203 \\
\pm 0.169\end{array}$ & - & $\begin{array}{l}0.122 \\
\pm 0.116\end{array}$ & - & $\begin{array}{l}0.070 \\
\pm 0.075\end{array}$ & - & $\begin{array}{l}0.063 \\
\pm 0.075\end{array}$ & - & $\begin{array}{l}0.061 \\
\pm 0.075\end{array}$ & - \\
\hline $\begin{array}{c}\text { Treatment I } \\
\text { (Sampling port 2) }\end{array}$ & $\begin{array}{l}0.201 \\
\pm 0.096\end{array}$ & $\begin{array}{c}0.6 \\
(0.98)\end{array}$ & $\begin{array}{l}0.124 \\
\pm 0.055\end{array}$ & $\begin{array}{l}-1.4 \\
(0.97)\end{array}$ & $\begin{array}{c}0.064 \\
\pm 0.044\end{array}$ & $\begin{array}{c}9.4 \\
(0.85)\end{array}$ & $\begin{array}{l}0.057 \\
\pm 0.043\end{array}$ & $\begin{array}{l}10.5 \\
(0.85)\end{array}$ & $\begin{array}{c}0.054 \\
\pm 0.043\end{array}$ & $\begin{array}{l}11.9 \\
(0.84)\end{array}$ \\
\hline $\begin{array}{c}\text { Treatment II } \\
\text { (after UV-A, } \\
\text { sampling port 3) }\end{array}$ & $\begin{array}{c}0.201 \\
\pm 0.082\end{array}$ & $\begin{array}{c}0.0 \\
(0.99)\end{array}$ & $\begin{array}{c}0.139 \\
\pm 0.077\end{array}$ & $\begin{array}{l}-10.7 \\
(0.72)\end{array}$ & $\begin{array}{c}0.081 \\
\pm 0.074\end{array}$ & $\begin{array}{l}-21.4 \\
(0.64)\end{array}$ & $\begin{array}{c}0.073 \\
\pm 0.075\end{array}$ & $\begin{array}{l}-21.9 \\
(0.67)\end{array}$ & $\begin{array}{c}0.067 \\
\pm 0.077\end{array}$ & $\begin{array}{l}-19.2 \\
(0.73)\end{array}$ \\
\hline
\end{tabular}

Note: Conc $=$ concentration, $\% \mathrm{R}=$ percent reduction, UV-A dose $=5.3 \mathrm{~mJ} \cdot \mathrm{cm}^{-2}$; sampling port numbers and locations are illustrated in Methods. 
MERV filtration was effective in removing airborne PM, regardless of the inherent variability in PM concentrations. As expected, it was verified that UV-A photocatalysis did not reduce PM. Variation in the real-time measured PM under the 'best-case', 'midpoint', and 'worst-case' scenarios for PM filtration prior to the UV treatment is illustrated in Supplementary Material (Figures S1-S3). The measured PM concentrations varied at $\sim 4 \times$ the order of magnitude around the mean. Such variability is typical [21] (i.e., the PM concentration in the manure pit headspace is instantaneously affected by barn ventilation, ambient air wind velocity, and wind direction). Additionally, the PM 'Control' concentrations, particulate size distribution, and composition vary with major diurnal and seasonal trends. Thus, variability in PM is a consideration in data analysis.

\subsection{Treatment of Airborne Pathogens with UV-A Photocatalysis}

UV-A photocatalysis treatment reduced CFU by $15-95 \%$ (Table 4). The CFU percent reduction was higher when airborne PM concentration was low ('best-case' > 'worst-case'). To be specific, the 'best-case' PM filtering scenario resulted in the same-day reductions from 2930 to 133 CFUs and 1000 to 67 CFUs (i.e., 95\% and 93\% percent reduction). However, CFU counts were lowered such that measurements produced Control and UV treatment values outside of each other's standard deviations (i.e., the variability meant that $p$-values did not meet the usual $<0.05$ test for statistical significance).

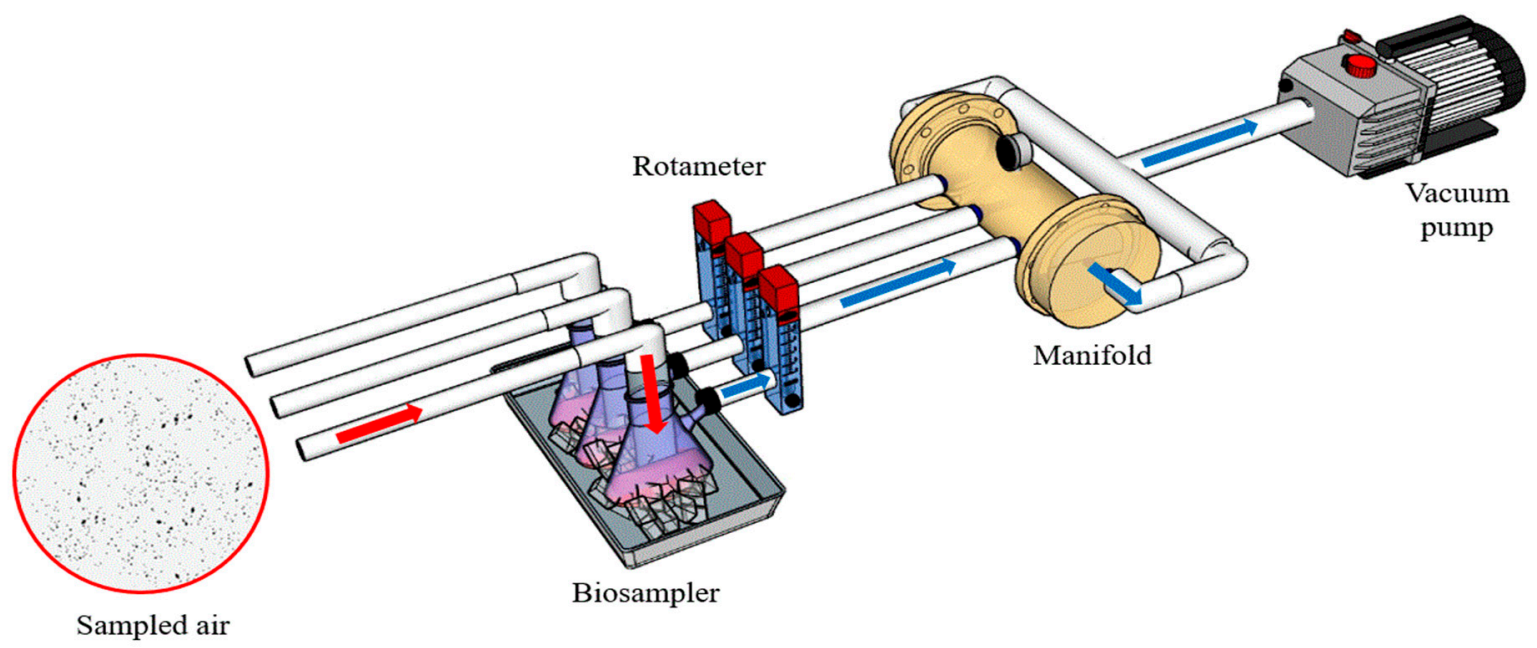

Figure 2. Schematic of an airborne pathogen sampling system. Red arrow: Sampled air with the viable and non-viable particulate matter emitted from the swine barn ventilation fan and trapped in biosample impingers; Blue arrow: Vacuuminduced airflow.

Table 4. CFU removal performance of UV-A photocatalysis (Treatment II) in mitigating airborne pathogens. Comparison of CFU before and after UV-A photocatalysis and resulting percent reduction.

\begin{tabular}{|c|c|c|c|c|c|c|c|c|c|c|}
\hline \multirow{2}{*}{ Scenario } & \multicolumn{4}{|c|}{$\begin{array}{c}\text { Control } \\
\text { (Inlet to UV Mobile Lab, Location \#2, Figure 2) }\end{array}$} & \multicolumn{4}{|c|}{$\begin{array}{c}\text { UV Treatment } \\
\text { (Outlet of UV Mobile Lab, Location \#3, Figure 2) }\end{array}$} & \multirow{2}{*}{ \% Reduction } & \multirow{2}{*}{$p$-Value } \\
\hline & $\begin{array}{c}\mathrm{C} 1 \\
\text { (CFU) }\end{array}$ & $\begin{array}{c}\mathrm{C} 2 \\
\text { (CFU) }\end{array}$ & $\begin{array}{c}\mathrm{C} 3 \\
\text { (CFU) }\end{array}$ & Mean \pm S.D. & $\begin{array}{c}\text { T1 } \\
\text { (CFU) }\end{array}$ & $\begin{array}{c}\text { T2 } \\
\text { (CFU) }\end{array}$ & $\begin{array}{c}\text { T3 } \\
\text { (CFU) }\end{array}$ & Mean \pm S.D. & & \\
\hline \multirow{2}{*}{ 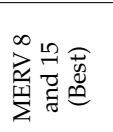 } & $5.0 \times 10^{3}$ & $2.0 \times 10^{2}$ & $3.6 \times 10^{3}$ & $2930 \pm 2470$ & $4.0 \times 10^{2}$ & 0 & 0 & $133 \pm 231$ & 95 & 0.17 \\
\hline & $6.0 \times 10^{2}$ & $2.4 \times 10^{3}$ & 0 & $1000 \pm 1250$ & $2.0 \times 10^{2}$ & 0 & 0 & $67 \pm 115$ & 93 & 0.34 \\
\hline 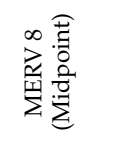 & $6.8 \times 10^{3}$ & $7.2 \times 10^{3}$ & $9.8 \times 10^{3}$ & $7930 \pm 1630$ & $5.0 \times 10^{3}$ & $5.0 \times 10^{3}$ & $5.8 \times 10^{3}$ & $5270 \pm 462$ & 34 & 0.06 \\
\hline \multirow{2}{*}{ 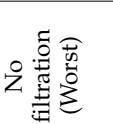 } & $1.3 \times 10^{4}$ & $1.2 \times 10^{4}$ & $1.1 \times 10^{4}$ & $12,100 \pm 1410$ & $9.6 \times 10^{3}$ & $7.8 \times 10^{3}$ & $1.3 \times 10^{4}$ & $10,300 \pm 2860$ & 15 & 0.52 \\
\hline & $6.4 \times 10^{4}$ & $2.8 \times 10^{4}$ & $1.6 \times 10^{4}$ & $36,300 \pm 24,700$ & $2.4 \times 10^{4}$ & $2.6 \times 10^{4}$ & $1.6 \times 10^{4}$ & $21,900 \pm 5500$ & 40 & 0.38 \\
\hline
\end{tabular}


Despite $p$-values that did not meet the usual statistical cut-off of $<0.05$ for significance, the large variability of the CFU control samples (Table 4), the numeric results suggest a real effect. A normalization procedure that accounts for the wide variability of the control data is discussed paragraphs below.

\section{Normalization of the Data}

Unlike experimental conditions, variability in PM (including viable PM) concentrations and in laboratory-based CFU enumeration cannot be controlled in the field. Therefore, the CFU and PM data were normalized (see Materials and Methods Equations (2) and (3)) prior to analysis. Statistical analysis of normalized data revealed that UV-A treatment had a significant effect on the partial filtration case $\left(\% R\right.$ for $C F U_{D}=43 \%, p$-value $=0.04$, Table 5$)$.

Table 5. CFU removal performance of UV-A photocatalysis (Treatment II) in mitigating airborne pathogens. Comparison of $\mathrm{CFU}_{\mathrm{D}}\left(\mathrm{CFU} \cdot \mathrm{m}^{-3}\right)$ normalized by the total PM concentration $\left(\mu \mathrm{g} \cdot \mathrm{m}^{-3}\right)$ before and after UV-A photocatalysis $(\mathrm{CFU} \mathrm{PM}$, $\left.\mathrm{CFU} \cdot \mu \mathrm{g}^{-1}\right)$ and resulting percent reduction. Bold signifies statistical significance.

\begin{tabular}{|c|c|c|c|c|c|c|c|c|c|c|}
\hline \multirow[b]{2}{*}{ Scenario } & \multicolumn{4}{|c|}{ Control } & \multicolumn{4}{|c|}{ UV Treatment } & \multirow{2}{*}{$\stackrel{\%}{\%}$ Reduction } & \multirow{2}{*}{$\begin{array}{c}p- \\
\text { Value }\end{array}$} \\
\hline & $\begin{array}{c}\mathrm{C} 1 \\
\left(\mathrm{CFU} U_{\mathrm{PM}}\right)\end{array}$ & $\begin{array}{c}\mathrm{C} 2 \\
\left(\mathrm{CFU}_{\mathrm{PM}}\right)\end{array}$ & $\begin{array}{c}\mathrm{C} 3 \\
\left(\mathrm{CFU}_{\mathrm{PM}}\right)\end{array}$ & Mean \pm S.D. & $\begin{array}{c}\mathrm{T} 1 \\
\left(\mathrm{CFU}_{\mathrm{PM}}\right)\end{array}$ & $\begin{array}{c}\mathrm{T} 2 \\
\left(\mathrm{CFU}_{\mathrm{PM}}\right)\end{array}$ & $\begin{array}{c}\mathrm{T} 3 \\
\left(\mathrm{CFU}_{\mathrm{PM}}\right)\end{array}$ & Mean \pm S.D. & & \\
\hline \multirow{2}{*}{ 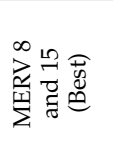 } & 1890 & 76 & 1361 & $1110 \pm 933$ & 148 & 0 & 0 & $49 \pm 86$ & 96 & 0.17 \\
\hline & 965 & 241 & 0 & $402 \pm 502$ & 57 & 0 & 0 & $19 \pm 33$ & 95 & 0.29 \\
\hline 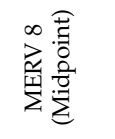 & 302 & 320 & 435 & $352 \pm 72$ & 192 & 192 & 222 & $202 \pm 18$ & 43 & 0.04 \\
\hline \multirow{2}{*}{ 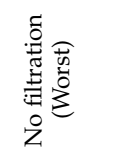 } & 393 & 358 & 311 & $354 \pm 41$ & 228 & 186 & 319 & $244 \pm 68$ & 31 & 0.20 \\
\hline & 623 & 269 & 163 & $352 \pm 241$ & 174 & 189 & 117 & $160 \pm 38$ & 55 & 0.28 \\
\hline
\end{tabular}

Additional data analyses were performed to deconvolute the effect of UV treatment on airborne pathogens when normalized by measured PM concentrations at different sizes. Thus, the average of $C F U_{P M}$ values was normalized by different PM sizes' concentrations under three different PM scenarios ('best-case', 'midpoint', and 'worst-case'; Table S1) and then compared the Control and Treatment (Table 6). The rationale was consistent with the fact that the PM size of airborne bacteria and viruses favors their overall contribution to the fine particulate (e.g., PM 2.5, PM 1). This had two practical implications; first, the averaging reduced some of the previously observed variability. Second, it removed the filtration effect altogether from the study (a filtration effect would affect both the Control and UV treatment the same; thus, it cancels out when the difference is calculated).

Significant mitigation (49-51\%) effect of UV-A photocatalysis on pathogen inactivation was reported in this study when considered in the context of the PM load and PM size ranges (Table 6), in particular for respirable, PM 2.5 and PM 1. Notably, normalization by smaller PM size range concentrations leads to emerging significant differences, while total and larger PM sizes (e.g., PM 10) did not indicate a statistically significant difference.

The results of this research support the anti-microbial effects of UV-A. UV-A is less bactericidal than UV-C [4,22]. However, a bactericidal effect has been reported for UV-A at sufficient dosage $[23,24]$ under laboratory conditions. It is well recognized that it is generally necessary to use the shorter wavelength for germicidal purposes because only at shorter wavelengths to DNA and proteins efficiently absorb the light and thus are subject to photoinduced damage. Gayan et al. (2013) [25] estimated that 100,000 times higher UV-A 
dose is needed than UV-C for the bacteria cells to form pyrimidine dimers (the primary deleterious photochemical event for DNA), which interfere with DNA replication.

Table 6. CFU removal performance of UV-A photocatalysis (Treatment II) in mitigating airborne pathogens. Comparison of $\mathrm{CFU}_{\mathrm{D}}\left(\mathrm{CFU} \cdot \mathrm{m}^{-3}\right)$ normalized by the different particle size (total, PM 10, PM respirable, PM 2.5, PM 1) concentrations $\left(\mu \mathrm{g} \cdot \mathrm{m}^{-3}\right)$ before and after UV-A photocatalysis $\left(\mathrm{CFU}_{\mathrm{PM}}, \mathrm{CFU} \cdot \mu \mathrm{g}^{-1}\right)$. Bold signifies statistical significance.

\begin{tabular}{|c|c|c|c|c|c|c|}
\hline Scale & Mean Control & Mean Treatment & $\begin{array}{c}\text { Mean } \\
\text { Difference }\end{array}$ & $\begin{array}{c}\text { Test } \\
\text { Statistic }\end{array}$ & $\begin{array}{c}\% \\
\text { Reduction }\end{array}$ & $p$-Value \\
\hline Raw CFU & 12,000 & 7387 & 4613 & 1.80 & 38 & 0.147 \\
\hline $\begin{array}{c}\mathrm{CFU}_{\mathrm{D}}\left(\mathrm{CFU} \cdot \mathrm{m}^{-3}\right) \text { normalized } \\
\text { by Total PM }\end{array}$ & 514 & 135 & 379 & 2.15 & 64 & 0.098 \\
\hline $\begin{array}{c}\mathrm{CFU}_{\mathrm{D}}\left(\mathrm{CFU} \cdot \mathrm{m}^{-3}\right) \text { normalized } \\
\text { by PM } 10\end{array}$ & 637 & 247 & 389 & 1.83 & 61 & 0.078 \\
\hline $\begin{array}{c}\mathrm{CFU}_{\mathrm{D}}\left(\mathrm{CFU} \cdot \mathrm{m}^{-3}\right) \text { normalized } \\
\text { by Respirable PM }\end{array}$ & 1053 & 519 & 534 & 3.35 & 51 & 0.014 \\
\hline $\begin{array}{c}\mathrm{CFU}_{\mathrm{D}}\left(\mathrm{CFU} \cdot \mathrm{m}^{-3}\right) \text { normalized } \\
\text { by PM } 2.5\end{array}$ & 1236 & 608 & 628 & 4.24 & 51 & 0.007 \\
\hline $\begin{array}{c}\mathrm{CFU}_{\mathrm{D}}\left(\mathrm{CFU} \cdot \mathrm{m}^{-3}\right) \text { normalized } \\
\text { by PM } 1\end{array}$ & 1293 & 660 & 633 & 4.03 & 49 & 0.008 \\
\hline
\end{tabular}

Note: The responses were averaged over the three replicates (C1, C2, C3 and T1, T2, T3 in Table 5), i.e., $\mathrm{C}_{\mathrm{avg}}$ and $\mathrm{T}_{\mathrm{avg}}$, respectively. Then, the percent reduction (\% R) was estimated as the ratio of $\left(C_{a v g}-T_{a v g}\right) / C_{a v g}{ }^{*} 100 \%$. Test Statistic was estimated as the ratio of Mean Difference and the standard deviation of the difference and was distributed as t-distribution. Mean Difference = Mean Control-Mean Treatment. Mean Control and Mean Treatment = averages of normalized $\mathrm{CFU}_{\mathrm{D}}$ in Control and Treatment, respectively.

However, a handful of other biomolecules absorb out that far. Thus, a much higher UV-A dose (compared with UV-C) may still be 'germicidal'. For airborne bioaerosols (containing E. coli), Wang et al. (2019) [26] showed that direct irradiation with UV-A is effective, though much less so than UV-C $\left(0.5 \log _{10}\right.$ vs. $2.2 \log _{10}$ reduction under the same dose of $370 \mathrm{~J} \cdot \mathrm{m}^{-3}$ ). Song et al. (2019) [27] also proposed that UV-A irradiation with a lower dose can disturb bacteria cellular metabolism via photochemistry that produces reactive oxygen species (ROS) balance, which can delay growth, damage cellular membrane, cause protein oxidation and mutation, and decrease energy metabolism [28-32].

In contrast to direct irradiation, there is emerging evidence [33,34] that UVA-irradiated $\mathrm{TiO}_{2}$ (photocatalysis), can be responsible for a bactericidal effect. The primary physical difference, of course, is that the $\mathrm{TiO}_{2}$ is what absorbs the light and produces toxic oxidative species, rather than relying on direct absorption by the microbes. For example, Kuhn et al. (2003) [24] reported that under $\mathrm{TiO}_{2}$ photocatalysis, OH-radicals could be generated from water and oxygen, and they can directly destruct bacteria cell walls, with up to $6 \log _{10}$ reduction in E. coli after a $60 \mathrm{~min}$ period. In the work reported here, we tested a similar scenario (i.e., $\mathrm{TiO}_{2}$ irradiated with UV-A) and presented the results. We have previously observed that UV-A (without $\mathrm{TiO}_{2}$ ) was not effective on the PRRS virus [4]. Thus, we did not plan for "dark" exposure of the barn exhaust air to $\mathrm{TiO}_{2}$ or for the control experiment (against no $\mathrm{TiO}_{2}$ ) as there was no expectation for a significant mitigation of CFUs. Further investigation of the potential UV-A photocatalysis treatment of airborne pathogens is warranted, especially for indoor barn applications, where simultaneous mitigation of gaseous emissions could be tested.

Several improvements can be proposed to the PM sampling protocols, including selecting a fully mechanically ventilated barn and aiming for sampling periods of relative low variability in PM (e.g., nighttime, when the 'Control' is expected less variable). Further improvements could be made to optimize the airborne pathogen sampling to target specific microorganisms besides the total load.

\section{Materials and Methods}

\subsection{Viable Particulate Matter Sampling System}

The sampling system was designed to simultaneously collect replicate $(\mathrm{n}=3)$ airborne PM samples (Figure 2; Figures S4 and S5). Three polytetrafluoroethylenes (PTFE) tubes 
were inserted into the treated air via the sampling ports (Figure S6), then connected to impingers (Biosampler, SKC Inc., Eighty Four, PA, USA). The impingers captured airborne PM using the culture medium ( $20 \mathrm{~mL}$ of brain heart infusion broth, $\mathrm{BHI}$ ) and $0.1 \%(v / v)$ antifoam A emulsion with a flow rate of $20 \mathrm{~L} \cdot \mathrm{min}^{-1}$ (Figure S7). Impingers were placed in a container filled with ice during sampling (Figure S7). Each impinger's sampled airflow rate was adjusted by a rotameter (Dwyer Instruments Inc., Michigan City, IN, USA) (Figures S5, S8 and S9). The manifold system was made for the vacuum distribution and simultaneous sample collection into three impingers. PVC adapter (ID $=89 \mathrm{~mm}$, Lowes, Ames, IA, USA) and screw caps (ID $=89 \mathrm{~mm}$, Lowes, Ames, IA, USA) were used to close both ends of manifolds (Figure S4). PVC primer and cement were used to seal the gaps between these parts. A gauge (Grainger, Des Moines, IA, USA) was installed in the manifold to monitor the vacuum. A constant airflow through the manifold was facilitated by a vacuum pump (Becker Pumps Corp., Cuyahoga Falls, OH, USA). The vacuum pump was turned on first, reached $20 \mathrm{~L} \cdot \mathrm{min}^{-1}$ airflow setpoint in each rotameter, and was maintained during each experiment.

\subsection{Mobile Lab Setup in the Swine Farm}

The mobile laboratory had an adjustable airflow system $\left(0.28-1.25 \mathrm{~m}^{3} \cdot \mathrm{s}^{-1}\right)$ for mitigating emissions with UV-A photocatalysis [18-20]. The mobile lab was connected to the swine manure pit fan (Figure 3, Figure S10). The minimum treated airflow was used (facilitating $52 \mathrm{~s} \mathrm{UV-A} \mathrm{treatment} \mathrm{time} \mathrm{from} \mathrm{inlet} \mathrm{to} \mathrm{outlet} \mathrm{in} \mathrm{the} \mathrm{mobile} \mathrm{laboratory)} \mathrm{in}$ this experiment for maximizing the treatment time and the potential for mitigation effect. Additionally, the highest UV-A intensity $\left(0.41 \mathrm{~mW} \cdot \mathrm{cm}^{-2}\right)$ was used (Figure S11) for the same purpose. Detailed information on the UV-A dose, light intensity, treatment time, airflow, and the testing farm was published in Lee et al., 2021 [20].

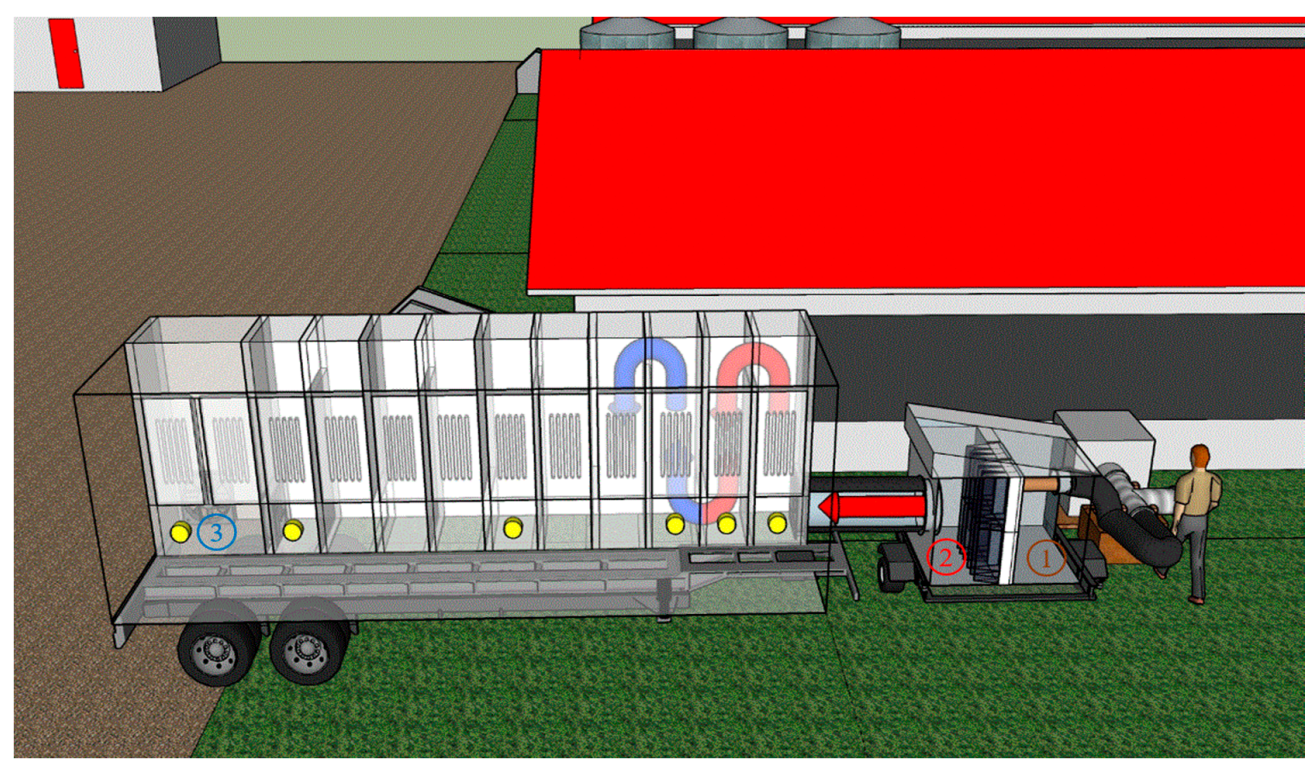

Figure 3. Schematic of particulate matter and airborne pathogens sampling ports (yellow) in the UV mobile laboratory and filtration system. Three-dimensional 'arrows' represent free airflow. (1) Brown 'arrow': Exhaust air from swine barn fan; (2) Red 'arrow': Inlet air with reduced particle matter load after MERV filtration; (3) Blue 'arrow': Treated air with UV-A photocatalysis.

The rationale for using the filtration upstream of UV treatment was to control the airborne PM concentrations and facilitate the separation of treatment effects between the UV and filtration (Figures S5 and S12). A total of three PM concentration levels (conditions) were generated for testing the UV treatment in the mobile laboratory by using two HEPA filters (MERV 8 and 15, detailed information was shown in the previous research, Lee et al., 2021 [18]). 
- $\quad$ The 'best-case' scenario-MERV 8 and 15 filters out most PM prior to UV treatment.

- The 'midpoint' scenario-partial filtration and a moderate PM load in the treated air. Only MERV 8 filter removes a fraction of airborne PM prior to the UV treatment.

- The 'worst-case' scenario-no PM filtration. Raw swine barn exhaust discharged from the manure pit is treated by UV.

\subsection{UV-A Dose}

The maximum UV-A dose $\left(5.3 \mathrm{~mJ} \cdot \mathrm{cm}^{-2}\right)$ provided by the mobile lab was then used to determine the mitigation effect of airborne pathogens. The UV-A dose was estimated as the average of the irradiated $\mathrm{UV}$ doses on all surfaces coated with $\mathrm{TiO}_{2}$ (nanostructured $\mathrm{TiO}_{2}$ anatase at $10 \mu \mathrm{g} \cdot \mathrm{cm}^{-2}$ from PureTi, Cincinnati, OH, USA) of the mobile lab. Each chamber inside the mobile laboratory was equipped with $5 \mathrm{UV}-\mathrm{A}$ LED lamps $\left(0.04 \mathrm{~mW} \cdot \mathrm{m}^{-2}\right.$ intensity, $47.6 \mathrm{~s}$ treatment time). The treatment time represents a realistic residence time in mechanically ventilated barns. An additional $100 \mathrm{UV}-\mathrm{A}$ lamps $\left(0.41 \mathrm{~mW} \cdot \mathrm{m}^{-2}, 9.5 \mathrm{~s}\right)$ were installed on a removable rack in chambers \#2-\#3 to maximize UV dose. The UV-A LED light used (T8 LED, Eildon Technology, Shenzhen, China) had $367 \mathrm{~nm}$ as the dominant wavelength (Figure S11). Detailed information on the measurements of UV-A light intensity, treatment time, photocatalyst, and UV lamps is published elsewhere [18].

\subsection{Enumeration of Total Colony-forming Unit}

The procedure for total plate count was performed according to Laird et al., 2004 [35], with minor modifications. Briefly, air samples collected in $20 \mathrm{~mL}$ of brain heart infusion broth (BHI) (Remel INC, San Diego, CA, USA) were centrifuged at 400G for $10 \mathrm{~min}$, at room temperature. Then, $15 \mathrm{~mL}$ was pipetted out of the tube, and the remaining $5 \mathrm{~mL}$ were homogenized by vortexing. For CFU determination, serial ten-fold dilutions were prepared by pipetting $0.1 \mathrm{~mL}$ of the sample into $0.9 \mathrm{~mL}$ of phosphate buffer. Next, $0.1 \mathrm{~mL}$ of each dilution and the undiluted sample were inoculated onto the $5 \%$ sheep blood in tryptic soy agar (Hardy Diagnostics, Chicago, IL, USA) plates. The liquid was spread into the agar with a sterile loop, immobilizing the cells on the surface of the agar and allowing the growth of distinct, non-overlapping colonies on the agar plates. The agar plates were incubated for $48 \mathrm{~h}$ at $37^{\circ} \mathrm{C}$, and colony-forming units (CFU) were counted at that dilution where 20-200 CFU were visible for counting (Figures S13 and S14). Impingers, air sampling tubing, and connectors were autoclaved between trials (Figure S15).

\subsection{Measurement of Non-Viable Particulate Matter Size and Concentrations}

The PM concentration was measured using TSI DustTrak (Monitor 8533, Shoreview, MN, USA). Real-time airborne PM concentrations were measured at five size ranges (PM 1, PM 2.5, 'respirable,' PM 10, and total PM) for $1 \mathrm{~h}$. The 'respirable' was defined as the 'PM 4 to PM 10' range (Figures S1-S13). The airborne pathogens were sampled simultaneously with the PM real-time measurements for $1 \mathrm{~h}$.

\subsection{Photocatalyst $\left(\mathrm{TiO}_{2}\right)$ Coating}

The $\mathrm{TiO}_{2}$ coating application was described in detail in previous studies [18-20]. Briefly, the application of the $\mathrm{TiO}_{2}$ coating on the pre-cut FRP (fiberglass reinforced plastic) panels for the UV reactor was carried out based on an application protocol provided by catalyst manufacturer (PureTi, Cincinnati, OH, USA). In addition, training was provided by SATA (Spring Valley, MN, USA) for accurate catalyst spraying control. The temperature $\left(25^{\circ} \mathrm{C}\right)$ and relative humidity $(40-45 \%)$ were adjusted to prevent instant evaporation of the sprayed $\mathrm{TiO}_{2}$ solution (nanostructured anatase $10 \mu \mathrm{g} \cdot \mathrm{cm}^{-2} \mathrm{TiO}, \mathrm{PureTi}$, Cincinnati, $\mathrm{OH}, \mathrm{USA}$ ) before application. $\mathrm{The} \mathrm{TiO}_{2}$ solution was then sprayed after cleaning the surface of the panel. The spray pressure was $60 \mathrm{psi}$, and the distance between the panel and the spray nozzle was maintained at $\sim 0.15 \mathrm{~m}$ ( $6 \mathrm{in})$ and perpendicular to the surface. Coated panels were dried at room temperature for 3 days. The SEM-EDS analyses of the applied $\mathrm{TiO}_{2}$ coating were described elsewhere [18]. 


\subsection{Data Analysis}

The rotameter's (Figure 1) reading of the airflow rate for each impinger was corrected to the standard temperature and pressure using Equation (1) [36]:

$$
\mathrm{Q}_{\mathrm{st}}=\mathrm{Q}_{\mathrm{ob}} \times \sqrt{\frac{\mathrm{P}_{\mathrm{ob}} \times \mathrm{T}_{\mathrm{st}}}{\mathrm{P}_{\mathrm{st}} \times \mathrm{T}_{\mathrm{ob}}}}
$$

where $\mathrm{Q}_{\text {st }}=$ standard flow corrected for pressure and temperature (normal temperature and pressure condition, $20^{\circ} \mathrm{C}$, and $\left.14.5 \mathrm{psi}, \mathrm{L} \cdot \mathrm{min}^{-1}\right), \mathrm{Q}_{\mathrm{ob}}=$ measured flowmeter reading from rotameter $\left(\mathrm{L} \cdot \mathrm{min}^{-1}\right), \mathrm{P}_{\mathrm{st}}=$ standard pressure $(1 \mathrm{~atm}, 14.7 \mathrm{psi}), \mathrm{P}_{\mathrm{ob}}=$ measured absolute pressure (psi): atmospheric pressure $(14.7 \mathrm{psi}) \pm$ gauge pressure $(\mathrm{psi}), \mathrm{T}_{\mathrm{st}}=$ standard temperature $(293.15 \mathrm{~K})$, and $\mathrm{T}_{\mathrm{ob}}=$ measured temperature $\left(273.15+\mathrm{T}^{\circ} \mathrm{C}\right)$.

The obtained $\mathrm{CFU}$ was divided by the airflow rate adjusted to normal temperature and pressure (NTP, defined as $20^{\circ} \mathrm{C}$ and $1 \mathrm{~atm}$ ), the number of CFU per sampled air volume for $1 \mathrm{~h}$ was estimated (Equation (2)).

$$
\mathrm{CFU}_{\mathrm{D}}=\frac{\mathrm{CFU}}{\mathrm{V}_{\text {sampled air }}}
$$

where $\mathrm{CFU}_{\mathrm{D}}=$ density of sampled total $\mathrm{CFU}$ under NTP condition $\left(\mathrm{CFU} \cdot \mathrm{m}^{-3}\right), \mathrm{CFU}=$ measured total $\mathrm{CFU}$ per sample, and $\mathrm{V}_{\text {sampled air }}=$ total sampled air volume by each impinger for $1 \mathrm{~h}\left(\mathrm{~m}^{3}\right)$ at NTP.

Additional data analyses were performed to deconvolute the effect of UV treatment of airborne pathogens at different PM size ranges and when considered in the context of the PM load. The evidence of the PM load as a potential carrier of pathogens is illustrated in Figure S16. The value of $\mathrm{CFU}_{\mathrm{D}}$ was divided by the measured PM concentration to calculate the $\mathrm{CFU}_{\mathrm{PM}}$ (CFU per measured PM, Equation (3). These additional analyses aimed to reduce the inherent variability in the real-time PM concentrations and associated with the CFU enumeration. The detailed process of calculating the quantified $\mathrm{CFU}_{\mathrm{PM}}$ using Equations (1)-(3) was shown in Tables S2-S4.

$$
\mathrm{CFU}_{\mathrm{PM}}=\frac{\mathrm{CFU}_{\mathrm{D}}}{\mathrm{PM}} \times 1000
$$

where $\mathrm{CFU}_{\mathrm{PM}}\left(\mathrm{CFU} \cdot \mu \mathrm{g}^{-1}\right)=$ the ratio of $\mathrm{CFU}_{\mathrm{D}}\left(\mathrm{CFU} \cdot \mathrm{m}^{-3}\right)$ per PM concentration at a specific PM size range $\left(\mathrm{mg} \cdot \mathrm{m}^{-3}\right)$.

The mitigation effect was evaluated by the overall mean percent reduction $(\% \mathrm{R})$, Equation (4).

$$
\% \mathrm{R}=\frac{\text { Con }- \text { Treat }}{\text { Con }} \times 100
$$

where Con and Treat are $\mathrm{CFU}_{\mathrm{PM}}\left(\mathrm{CFU} \cdot \mu \mathrm{g}^{-1}\right)$ and PM concentration in Control and Treatment, respectively.

\subsection{Statistical Analyses}

The $\mathrm{R}$ (version 3.6.2) was used to analyze the mitigation effect under UV-A photocatalysis treatment (reported in Tables 1-5). The control CFU value and treatment CFU value were statistically analyzed using one-way ANOVA. The statistical difference was confirmed by obtaining the $p$-value through the Paired Tukey test. A significant difference was defined for a $p$-value $<0.05$.

An additional statistical model in $R$ (version 4.0.6) was used to assess the effectiveness of UV treatment then the raw CFU data were normalized by PM size (reported in Table 6). A paired $\mathrm{t}$-test was run over the averages of the three replicates. 


\section{Conclusions}

This proof-of-concept aimed to investigate whether particulate matter (PM) filtration (at MERV 8 and 15 range) and UV-A photocatalysis could reduce PM and airborne pathogens discharged from swine barn. The following general conclusions were made:

- MERV 8 and15 effectively mitigated PM concentrations (96-98\%, $p$ ranged from $<0.01$ to 0.04 ) in swine barn exhaust.

- UV-A photocatalysis does not affect PM concentrations in swine barn exhaust.

- UV-A photocatalysis treatment reduced CFU by $15-95 \%$. The CFU percent reduction was higher when airborne PM concentration was low ('best-case' > 'worst-case'). UV-A photocatalysis reduced the concentration of airborne pathogens ( $43 \%$ reduction, $p=0.04)$ in moderate PM concentration conditions.

- Despite $p$-values that did not meet the usual statistical cut-off of $<0.05$ for significance, the large variability of the CFU control samples, the numeric results suggested a real effect.

- Normalization of measured airborne pathogen concentrations by smaller PM size range concentrations led to emerging significant treatment differences for CFUs. Significant mitigation (49-51\%, $p$ ranged from 0.01 to 0.03 ) effect of UV-A photocatalysis on pathogen inactivation was observed when considered in the context of the PM load and PM size ranges in particular for the respirable, PM 2.5 and PM 1 (i.e., below the 10 micron range).

Additional improvements to the experimental approach for farm-scale testing were proposed, and further investigation is warranted.

Supplementary Materials: The following are available online at https:/ /www.mdpi.com/article/10 $.3390 /$ catal11111302/s1, Detailed PM and CFU data is presented in Figures S1-S3 and Tables S1-S4. Detailed information about the experimental setup and methods used is illustrated in Figures S4-S16.

Author Contributions: Conceptualization, M.L., J.A.K., N.R.M., and J.Z.; methodology, M.L., J.A.K., N.R.M., P.L., and J.Z.; validation, M.L., J.A.K., N.R.M., J.Z., and R.V.P.; formal analysis, M.L., N.R.M., and R.V.P.; investigation, M.L., N.R.M., B.C., and P.L.; resources, M.L., J.A.K., N.R.M., and J.Z.; data curation, M.L., J.A.K., and N.R.M.; writing—original draft preparation, M.L.; writing-review and editing, M.L., J.A.K., N.R.M., W.S.J., R.V.P., and J.Z.; visualization, M.L.; supervision, J.A.K.; project administration, J.A.K. and W.S.J.; funding acquisition, J.A.K. and W.S.J.; All authors have read and agreed to the published version of the manuscript.

Funding: This research was supported by Iowa Pork Producers Association Project \#18-089 “Employing environmental mitigation technology and/or practices: Treating swine odor and improving air quality with black light." In addition, this research was partially supported by the Iowa Agriculture and Home Economics Experiment Station, Ames, Iowa. Project no. IOW05556 (Future Challenges in Animal Production Systems: Seeking Solutions through Focused Facilitation) sponsored by Hatch Act and State of Iowa funds.

Institutional Review Board Statement: Not applicable. The animals were not used in this research. Informed Consent Statement: Not applicable.

Data Availability Statement: The original contributions presented in the study are included in the article/Supplementary Materials; further inquiries can be directed to the corresponding author.

Acknowledgments: The authors gratefully acknowledge Skyler P. Rinker and Jacob Parr (Iowa State University) for help with using farm AG450 for testing.

Conflicts of Interest: The authors do not declare a conflict of interest. The funders did not play any role in the study design, data collection, analysis, interpretation, and decision to write a manuscript or present results. 


\section{References}

1. Seedorf, J. An emission inventory of livestock-related bioaerosols for Lower Saxony, Germany. Atmos. Environ. 2004, 38, 6565-6581. [CrossRef]

2. Costa, A.; Borgonovo, F.; Leroy, T.; Berckmans, D.; Guarino, M. Dust concentration variation in relation to animal activity in a pig barn. Biosyst. Eng. 2009, 104, 118-124. [CrossRef]

3. Donham, K.J. Association of environmental air contaminants with disease and productivity in swine. Am. J. Vet. Res. 1991, 52, 1723-1730. [PubMed]

4. Li, P.; Koziel, J.A.; Zimmerman, J.J.; Zhang, J.; Cheng, T.; Yim-Im, W.; Jenks, W.S.; Lee, M.; Chen, B.; Hoff, S.J. Mitigation of Airborne PRRSV Transmission with UV Light Treatment: Proof-of-concept. Agriculture 2021, 11, 259. [CrossRef]

5. Dee, S.; Batista, L.; Deen, J.; Pijoan, C. Evaluation of an air-filtration system for preventing aerosol transmission of porcine reproductive and respiratory syndrome virus. Can. J. Vet. Res. 2005, 69, 293-298.

6. Dee, S.; Otake, S.; Deen, J. Use of a production region model to assess the efficacy of various air filtration systems for preventing airborne transmission of porcine reproductive and respiratory syndrome virus and Mycoplasma hyopneumoniae: Results from a 2-year study. Virus Res. 2010, 154, 177-184. [CrossRef] [PubMed]

7. Holtkamp, D.J.; Johnson, C.; Koziel, J.A.; Li, P.; Murray, D.; Ruston, C.R.; Stephan, A.; Torremorell, M.; Wedel, K. Ultraviolet C (UVC) Standards and Best Practices for the Swine Industry. Agric. Biosyst. Eng. Tech. Rep. White Pap. $2020,29$.

8. Costa, A.; Chiarello, G.L.; Selli, E.; Guarino, M. Effects of $\mathrm{TiO}_{2}$ based photocatalytic paint on concentrations and emissions of pollutants and on animal performance in a swine weaning unit. J. Environ. Manag. 2012, 96, 86-90. [CrossRef]

9. Guarino, M.; Costa, A.; Porro, M. Photocatalytic $\mathrm{TiO}_{2}$ coating-to reduce ammonia and greenhouse gases concentration and emission from animal husbandries. Bioresour. Technol. 2008, 99, 2650-2658. [CrossRef]

10. Lee, M.; Wi, J.; Koziel, J.A.; Ahn, H.; Li, P.; Chen, B.; Meiirkhanuly, Z.; Banik, C.; Jenks, W. Effects of UV-A light treatment on ammonia, hydrogen sulfide, greenhouse gases, and ozone in simulated poultry barn conditions. Atmosphere 2020, 11, 283. [CrossRef]

11. Rockafellow, E.M.; Koziel, J.A.; Jenks, W.S. Laboratory-Scale Investigation of UV treatment of ammonia for livestock and poultry barn exhaust applications. J. Environ. Qual. 2012, 41, 281-288. [CrossRef] [PubMed]

12. Koziel, J.A.; Yang, X.; Van Leeuwen, J.; Jenks, W.S.; Laor, Y. Treatment of odorous VOCs with ultraviolet light. Chem. Eng. Trans. 2010, 23, 363. [CrossRef]

13. Zhu, W.; Koziel, J.A.; Maurer, D.L. Mitigation of livestock odors using black light and a new titanium dioxide-based catalyst: Proof-of-concept. Atmosphere 2017, 8, 103. [CrossRef]

14. Lee, M.; Li, P.; Koziel, J.A.; Ahn, H.; Wi, J.; Chen, B.; Meiirkhanuly, Z.; Banik, C.; Jenks, W.S. Pilot-scale testing of UV-A light treatment for mitigation of $\mathrm{NH}_{3}, \mathrm{H}_{2} \mathrm{~S}$, GHGs, VOCs, odor, and $\mathrm{O}_{3}$ inside the poultry barn. Front. Chem. 2020, 8, 613. [CrossRef] [PubMed]

15. Maurer, D.L.; Koziel, J.A. On-farm pilot-scale testing of black ultraviolet light and photocatalytic coating for mitigation of odor, odorous VOCs, and greenhouse gases. Chemosphere 2019, 221, 778-784. [CrossRef] [PubMed]

16. Koziel, J.A.; Yang, X.; Cutler, T.; Zhang, S.; Zimmerman, J.J.; Hoff, S.J.; Jenks, W.S.; Laor, Y.; Ravid, U.; Armon, R. Mitigation of odor and pathogens from $\mathrm{CAFOs}$ with $\mathrm{UV} / \mathrm{TiO}_{2}$ : Exploring the cost effectiveness. In Proceedings of the Mitigating Air Emissions from Animal Feeding Operations, Des Moines, IA, USA, 19-21 May 2008; pp. 169-173.

17. Yang, X.; Koziel, J.A.; Laor, Y.; Zhu, W.; Van Leeuwen, J.H.; Jenks, W.S.; Hoff, S.J.; Zimmerman, J.; Zhang, S.; Ravid, U. VOC removal from manure gaseous emissions with UV photolysis and $\mathrm{UV}_{-} \mathrm{TiO}_{2}$ photocatalysis. Catalysts 2020, 10, 607. [CrossRef]

18. Lee, M.; Koziel, J.A.; Murphy, W.; Jenks, W.S.; Fonken, B.; Storjohann, R.; Chen, B.; Li, P.; Banik, C.; Wahe, L. Design and testing of mobile laboratory for mitigation of gaseous emissions from livestock agriculture with photocatalysis. Int. J. Environ. Res. Public Health 2021, 18, 1523. [CrossRef] [PubMed]

19. Lee, M.; Koziel, J.A.; Murphy, W.; Jenks, W.S.; Chen, B.; Li, P.; Banik, C. Evaluation of $\mathrm{TiO}_{2}$ based photocatalytic treatment of odor and gaseous emissions from swine manure with UV-A and UV-C. Animals 2021, 11, 1289. [CrossRef]

20. Lee, M.; Koziel, J.A.; Murphy, W.; Jenks, W.S.; Chen, B.; Li, P.; Banik, C. Mitigation of Odor and Gaseous Emissions from Swine Barn with UV-A and UV-C Photocatalysis. Atmosphere 2021, 12, 585. [CrossRef]

21. Heber, A.J.; Lim, T.T.; Ni, J.Q.; Tao, P.C.; Schmidt, A.M.; Koziel, J.A.; Hoff, S.J.; Jacobson, L.D.; Zhang, Y.; Baughman, G.B. Quality assured measurements of animal building emissions: Particulate matter concentrations. J. Air Waste Manag. Assoc. 2006, 56, 1642-1648. [CrossRef]

22. Le, T.T.N.; Nagata, H.; Takahashi, A.; Aihara, M.; Okamoto, T.; Shimohata, T.; Mawatari, K.; Akutagawa, M.; Kinouchi, Y.; Haraguchi, M. Sterilization effect of UV light on Bacillus spores using $\mathrm{TiO}_{2}$ films depends on wavelength. J. Med. Investig. 2012, 59, 53-58. [CrossRef]

23. Ramesh, T.; Yaparatne, S.; Tripp, C.P.; Nayak, B.; Amirbahman, A. Ultraviolet light-assisted photocatalytic disinfection of Escherichia coli and its effects on the quality attributes of white grape juice. Food Bioprocess Technol. 2018, 11, $2242-2252$. [CrossRef]

24. Kühn, K.P.; Chaberny, I.F.; Massholder, K.; Stickler, M.; Benz, V.W.; Sonntag, H.G.; Erdinger, L. Disinfection of surfaces by photocatalytic oxidation with titanium dioxide and UVA light. Chemosphere 2003, 53, 71-77. [CrossRef]

25. Gayán, E.; Condón, S.; Álvarez, I. Biological aspects in food preservation by Ultraviolet Light: A Review. Food Bioprocess Technol. 2013, 7, 1-20. [CrossRef] 
26. Wang, C.; Lu, S.; Zhang, Z. Inactivation of airborne bacteria using different UV sources: Performance modeling, Energy Utilization, and endotoxin degradation. Sci. Total Environ. 2019, 655, 787-795. [CrossRef] [PubMed]

27. Song, K.; Mohseni, M.; Taghipour, F. Mechanisms investigation on bacterial inactivation through combinations of UV wavelengths. Water Res. 2019, 163, 114875. [CrossRef] [PubMed]

28. Bosshard, F.; Riedel, K.; Schneider, T.; Geiser, C.; Bucheli, M.; Egli, T. Protein oxidation and aggregation in UvA-irradiated escherichia coli cells as signs of accelerated cellular senescence. Environ. Microbiol. 2010, 12, 2931-2945. [CrossRef] [PubMed]

29. Girard, P.M.; Francesconi, S.; Pozzebon, M.; Graindorge, D.; Rochette, P.; Drouin, R.; Sage, E. UVA-induced damage to DNA and proteins: Directversusindirect photochemical processes. J. Phys. Conf. Ser. 2011, 261, 012002. [CrossRef]

30. Hoerter, J.D.; Arnold, A.A.; Kuczynska, D.A.; Shibuya, A.; Ward, C.S.; Sauer, M.G.; Gizachew, A.; Hotchkiss, T.M.; Fleming, T.J.; Johnson, S. Effects of sublethal UVA irradiation on activity levels of oxidative defense enzymes and protein oxidation in escherichia coli. J. Photochem. Photobiol. B Biol. 2005, 81, 171-180. [CrossRef]

31. Oppezzo, O.J.; Pizarro, R.A. Sublethal effects of ultraviolet a radiation on Enterobacter cloacae. J. Photochem. Photobiol. B Biol. 2001, 62, 158-165. [CrossRef]

32. Ramabhadran, T.V.; Jagger, J. Mechanism of growth delay induced in escherichia coli by near ultraviolet radiation. Proc. Natl. Acad. Sci. USA 1976, 73, 59-63. [CrossRef] [PubMed]

33. Zacarías, S.M.; Pirola, S.; Manassero, A.; Visuara, M.E.; Alfano, O.M.; Satuf, M.L. Photocatalytic inactivation of Bioaerosols in a fixed-bed reactor with Tio2-coated glass rings. Photochem. Photobiol. Sci. 2019, 18, 884-890. [CrossRef] [PubMed]

34. Pal, A.; Min, X.; Yu, L.E.; Pehkonen, S.O.; Ray, M.B. Photocatalytic inactivation of bioaerosols by tio2 coated membrane. Int. J. Chem. React. Eng. 2005, 3. [CrossRef]

35. Laird, D.T.; Gambrel-Lenarz, S.A.; Scher, F.M.; Graham, T.E.; Reddy, R. Microbiological Count Methods. In Standard Methods for the Examination of Dairy Products; Wehr, H.W., Frank, J.F., Eds.; American Public Health Association: Washington, DC, USA, 2004; pp. 153-186.

36. Li, P.; Koziel, J.; Zimmerman, J.; Hoff, S.; Zhang, J.; Cheng, T.; Yim-Im, W.; Lee, M.; Chen, B.; Jenks, W. Designing and Testing of a System for Aerosolization and Recovery of Viable Porcine Reproductive and Respiratory Syndrome Virus (PRRSV): Theoretical and Engineering Considerations. Front. Bioeng. Biotechnol. 2021, 9, 659609. [CrossRef] [PubMed] 